\title{
ZAGHLÛL RÂGHIB MUHAMMAD AL-NAJJÂR'S METHODS AND PRINCIPLES OF SCIENTIFIC EXEGESIS: A Review of Tafsîr al-Âyât al-Kawniyyah fî al-Qur'ân al-Karîm
}

Umaiyatus Syarifa $h^{\star}$ and Siti Fahimah ${ }^{\text {से }}$

* Universitas Islam Negeri Maulana Malik Ibrahim Malang, Indonesia

** Institut Agama Islam Tarbiyatut Tholabah Lamongan, Indonesia

E-mail: umayya_syarifa@fis.uin-malang.ac.id

\section{Abstract}

Scientific exegesis is one of the new trends in interpreting the Quran that will continue to be in demand. There are many discussions of science and Quran integration, and the rise of various works of scientific interpretation among scholars and scientists has become the real proof of it. However, some Muslim communities still doubt the validity of scientific interpretations. One of the reasons is because the source of the interpretation is relative and temporal. This evidence, of course, cannot be compared with the Quran, which is absolute. Therefore, a regulation is needed in the application of scientific interpretation. This study aims to examine and explore the methods and principles of the scientific interpretation of the Quran conducted by Zaghlûl Râghib al-Najjâr, in terms of their strengths, shortcomings, and relevance in the interpretation of the Quran. This research is considered qualitative research utilizing library research by analyzing some literatures such as books and journal articles. The results of this research show that the Zaghlûl as a Geologist, who is quite productive with the authority of science he has, does not only interpret Quran scientifically but also explains the procedure of interpretation through methods and principles of interpretation similar to scholars of tafsîr in general. In fact, he may be even be considered more 
specific and ideal compared to others because he not only complements but also enhances the guidelines and principles of the scientific exegesis that have been used before.

Al-tafsîr al-ilmî merupakan salah satu trend baru dalam penafsiran AlQur'an yang akan terus diminati. Maraknya diskusi seputar integrasi sains dan Al-Qur'an dan munculnya berbagai karya tafsir di kalangan ulama dan saintis menjadi bukti nyata akan hal tersebut. Namun, sebagian kalangan umat Islam masih meragukan keabsahan al-tafsîr al-ilmî, salah satu penyebabnya karena sumber penafsirannya yang bersifat relatif dan temporal. Hal ini tentunya tidak dapat disandingkan dengan Al-Qur'an yang bersifat absolut. Oleh karena itu, dibutuhkan sebuah regulasi dalam aplikasi penafsiran ilmiah. Penelitian ini bertujuan untuk mengkaji dan mengeksplorasi metode dan prinsip-prinsip penafsiran ilmiah yang dilakukan oleh Zaghlûl Râghib al-Najjâr untuk dapat ditelaah kekuatan, kekurangan, dan relevansinya dalam penafsiran Al-Qur'an. Jenis penelitian ini adalah kualitatif dan bersifat library research dengan menganalisis beberapa literatur seperti buku dan artikel jurnal. Hasil penelitian menunjukkan bahwa Zaghlûl sebagai seorang Geolog yang cukup produktif dengan otoritas keilmuan yang dimilikinya tidak hanya menafsirkan Al-Qur'an secara saintifik namun juga menjelaskan prosedur penafsiran ilmiah melalui metode dan prinsip-prinsip penafsiran sebagaimana ulama tafsir pada umumnya, bahkan dapat dikatakan lebih spesifik dan ideal. Zaghlûl melengkapi dan menyempurnakan kaedah dan prinsip-prinsip penafsiran ilmiah yang telah ada sebelumnya.

Keywords: methods and principles; scientific exegesis; Zaghlûl Râghib alNajjâr

Received: September 7, 2020; Accepted: December 17, 2020

\section{Introduction}

The desire of Muslims to continuously discuss the Quran as a text limited to the social issues of humanity and ever-developing science is a spirit of its own for the dynamics of the Quran interpretation studies. Even though Quran was revealed centuries ago, with its particular context and locality of certain social and cultural, it contains universal values that will always be relevant to every age and place (Shahrûr 1992, vol. 1). In line with 
the idea, according to Abdullah, the development of the political situation, culture, science, and the information revolution play a role in re-interpret religious texts (Abdullah 2000).

Therefore, as the people living in the modern-contemporary era, interpreting the Quran under the demands of the current era is necessary, without having to solely utilize the methods of previous scholars. This, however, needs alternative methods and epistemology under the development of the social situation, culture, science, and human civilization (Mustaqim 2010). One of the contemporary interpretation methods and epistemology which gains its popularity and development is the interpretation of the Quran based on empirical science ("Ammâr 2008), or popularly called as scientific exegesis of the Quran (al-tafsîr al-ilmî). Scientific exegesis's term was used by most Western scholars to refer al-tafsîr al-ilmî term, among others are Jansen, Baljon, Ansari, Mir, and Elshakri (Mohd, Husin, and Abdulah 2016; Syarifuddin and Azizy 2018; Syamimi Mohd, Hussin, and Nasyrudin Wan Abdullah 2014).

The scientific exegesis of the Quran attempts at connecting and discussing the kawniyyah verses with modern science invention that aims to prove the miracle of the Quran (al-Khâlidî 2008, 549; al-Raḥmân 1986, 566). According to al-Dhahabî, it is an interpretation taking scientific term in the verses of the Quran and trying to produce a variety of knowledge and some philosophical view (al-Dhahabî 1959, vol. 2, 349). It can be defined by explaining the meaning of Quran involving scientific information, both natural science and social science (Sayska and Arni 2016; Amir and Yusoff 2017; Bigliardi 2014).

In modern Western societies, scientific education and development overwhelmingly hold a central role. Hence, scientific exegesis of the Quran, expounding on verses dealing with scientific fact, is a re-emerging phenomenon. Though scientific exegesis Quranic exegesis has a long history, originating from within the writing al-Ghazâlî (d. 1111) through his works Jawâhir al-Qur'ân and Ihyâ 'Ulum al-Dîn and supported by while certain prominent Muslim scholars, like al-Râzî (d. 1209), al-Mursî, and alSuyûtî, its popularity in present time has reached unprecedented levels (Ali 2018; Mir 2004; Çoruh 2020; Mutalib et al. 2019).

The birth of scientific exegesis of the Quran cannot be separated from the influence of the West against the Arab world, especially Islam. Sciences developed rapidly in the West, but Islamic studies degraded more and finally emerged dichotomy between science and Islamic studies. 
Furthermore, the West also faced secularism in science that the church was also against it. This atmosphere motivates Muslim scholars to reintegrate science and religion (Awang et al. 2014, 39; Mufid 2014, 150). Scientific interpretation, with its modern form, is a part of the great debate taking place in the Muslim world since the beginning of the influence of technology, science, and politics of the West in the Arab World (Rahayu 2016; Sayska and Arni 2016; Supriadi 2017; Suskha, AM, and Wusqa 2020).

One of the Islamic countries that enliven the richness of scientific exegesis of the Quran is Egypt. As the center of civilization of Islamic school of thought, the attention towards the scientific exegesis of the Quran took place in the age of Muhammad 'Abduh. Though he might not be considered as a true partisan, 'Abduh was represented by some well-known scholars such as al-Iskandaranî, Aḥmad Mukhtâr al-Ghazî, 'Abd Allâh Fikrî Bâshâ (d. 1830), and Muhammad Tawfîq Ṣidqî (1881-1920) (Saleh 2011). He wrote some articles about the natural history published by the magazine al-Manâr.

The scientific exegesis of the Quran finds its perfect form through the work of Ṭanțâwî Jawharî (1940) (Muchlisin and Nisa 2017), followed by Farîd Wajdî (1940), 'Abd al-Raḥman al-Kawâkibî, Muṣtafâ Ṣadîq, Hanafî Ahmad (Jansen 1997; Mohd, Husin, and Abdulah 2014). Furthermore, not less interestingly, a man of science such as Zaghlûl Râghib al-Najjâr joins in enlivening the discourse of the development of scientific exegesis in Egypt.

However, there are three positions in historical debate about the issue of Quran and science in Islamic word: complete agreement, partial agreement, or no agreement at all (Companini 2005). A great number of tafsîr scholars who expressed dismay unhappiness with the use of science in interpretation of the Quran as advocated and applied in present times such including al-Shâtibî, al-Dhahabî, 'Izzah Darwazah, and Amîn al-Khûlî (Khir 2000). Although there have been pros and cons among Muslim scholars, scientific exegesis' existence cannot be ignored and will continue to be in demand. In fact, the study of Jansen over the development of scientific exegesis of the Quran concludes that the model of scientific exegesis will always find its place even in the future (Jansen 1997, 120).

Furthermore, it can be said the contribution of the Islamic scholars in the scientific exegesis of the Quran is divided in two forms. First is the form of the interpretation of the scientific verses without being accompanied by an explanation of the guidelines of scientific interpretation in concrete 
terms. The second is an explanation of the guidelines of scientific exegesis of the Quran without producing any product of interpretation. It is believed that the majority of the methods that have been applied only lead to the ethics of interpretation rather than the rules of scientific interpretation themselves (Hakim 2019). Ironically, those who pursued this new agenda (scientific exegesis) were neither scientists nor exegetes with formal training in the long-established tradition of the Quranic exegesis (Iqbal 2018, 280). Therefore, the scientific exegesis of the Quran written by academicians with a background in science is often considered madhmûm as it is considered as not qualified in the field of the Quran interpretation. In addition, it may be considered to have poor methods of interpretation, which leads to having interpretation result that seemed to be forced with scientific theories. This had happened to Nazwar Shamsu's interpretation which were withdrawn from publication.

To avoid and minimize the aforementioned issues, tafsîr scholars have been struggling to provide and explain what method should be used in interpreting scientific verses. In general, the method of scientific exegesis of the Quran provided by the scholars includes the following four main guidelines.

First is the rule of the language. This includes the science of $i^{\prime} r a \hat{b} b$, nahw, sarf,, and balagha. Second is the correlation between paragraphs (munâsabah âyât), both before and afterward (Shihab 2004, 241). Third, it should be based on an established scientific theory. Fourth, it should use thematic methods. Some other scholars add some rules such as the disciplines mastery of both religion and science. In addition, it is not recommended to claim the absolute truth of science theory as well as to shift the intrinsic meaning to the majâzi meaning (al-Najjâr 2008, vol. 1, 238).

Zaghlûl, a scientist and a scientific exegete of the Quran, who is quite popular in the Islamic world, interprets the scientific verses by explaining his interpretation method. The background knowledge possessed by Zaghlûl made his work considered ideal for the 21 st century, which is considered the peak of the rapid development of science and technology. Furthermore, Zaghlûl presents his work in the complete package, showing both his interpretation results and interpretation rules, which have been rarely done by earlier scholars. 
All this time, journal articles have focused more on Zaghlûl's biography, the epistemology of his interpretation, and the application of his interpretation of scientific verses (Amir et al. 2012; 2016; Shaleh and Mustikasari 2018). This research tries to review and explore the Zaghlûl's methods and principles to be reviewed in terms of its strengths, shortcomings, and relevance in the interpretation of the Quran. It is hoped that in the future, these methods and principles of interpretation can be used as a reference for researchers of scientific exegesis of the Quran in interpreting the scientific verse of the Quran. Through the methods and principles offered, Zaghlûl can prove the dialectic between kawniyyah verses and modern science at this time. It can be an alternative solution for a crucial problem in studying scientific interpretation debated among scholars.

\section{Zaghlûl Râghib al-Najjâr, Tafsîr Creation, and Scientific Authority}

Prof. Dr. Zaghlûl al-Najjâr's full name is Zaghlûl Râghib Muhammad al-Najjâr. He was born on 17 November 1933 in the Mashâl village, Bison, Egypt. He came from a religious family. His grandfather was an imam in his village, and his father was a hâfiz of the Quran. At the age of nine, Zaghlûl memorized the Quran, followed his father to move to Cairo, and continued his primary school there. In 1946, Zaghlûl finished elementary school and registered at Shoubra High School, and became one of the best graduates (al-Najjâr 2010, 9).

Zaghlûl's great interest in science led him to choosing Geology at the Faculty of Science, Cairo University, Egypt, which was a new faculty at that time. He completed his Bachelor's degree in 1955 with a Bachelor of Science degree with the first cum laude predicate, so the university awarded him Muștafâ Baraka in Geology. However, due to Zaghlûl's participation in one of the political demonstrations against the government, he was arrested after graduating from university to be tried and later released. His opportunity to become a dean candidate also disappeared due to political factors where he was considered affiliated with the Ikhwân al-Muslimûn (Abohashem 2012).

Zaghlûl decided to study at the University of Wales in England. He received a Master's degree and a Ph.D. in the same field from the university in 1963. In 1972, he was appointed as professor of Geology and received the title at the University of California LA United States of America (1977). At 67 years old, Zaghlûl was elected a rector of the Markfield Institute of 
Higher Education England and became the chairman of the Commission for the Scientific Miracle of the Quran and Sunnah in Egypt's Supreme Council of Islamic Affairs until now (Amir et al. 2016; Shaleh and Mustikasari 2018).

Zaghlûl's popularity was increasingly unstoppable as he was selected as a team editor for scientific journals such as The Journal of Foraminiferal Research published in New York, the Journal of African Earth Sciences published in Paris, as well as a consultant for scientific journals in India, Washington DC, England, and Qatar. He was also selected as a scientific consultant for the Museum of Islamic Civilization in Switzerland (2001). In addition, he was appointed as an oil consultant for the Arab-Kuwait and oil company in Khafijî (Amir, Noor, and Hilmi 2012, 57).

Zaghlûl published approximately eighty-five scientific papers in Geology, the majority of his research studied soil geology, soil analysis, and phosphates in Egypt, Kuwait, and petroleum reserves in Saudi Arabia. Zaghlûl also published forty scientific research in Islamic Science including evolution, geology from an Islamic perspective, science, and technology in Islamic society, and several works about criticism in Islamic education and teaching Geology at the university level. Some of his creations that are quite popular include Tafsîr al-Âyât al-Kawniyyah fî al-Qur'ân al-Karîm, Min Âyât alI'jâzz al-'Ilmî̀: al-Hayawân fî al-Qur'ân al-Karîm, Min Âyât al-I'jâz al-'Ilmî: al-Ardu fì al-Qur'ân al-Karîm, Wonderful Scientific Sign in The Qur'an, and many others (al-Najjâr 2008, vol. 1, 7).

Tafsir al-Âyât al-Kawniyyah fì al-Qur'ân al-Karîm is a tafsîr that contains selected verses that explain scientific facts in the Quran. This tafsir is the result of Zaghlûl's long work, published by Maktabat al-Shurûq alDawliyyah, Egypt, printed in August 2010 in four volumes. This tafsîr also has been translated into Indonesia language by Masrî el-Mahshâr Bidin et al., published by the Shorouk International Bookshop, Jakarta in September 2010 in a more concise form in three volumes.

The author of this research believes that the method of tafsir used by Zaghlûl is mawdîn $\hat{\imath}$ method, and it uses a scientific approach. Of the 144 suras in the Quran, he only chose 197 scientific verses found in 66 suras. He compiled the according to the order of the mushaf, then from the sura, Zaghlûl chose whole or a piece of verse that indicated a scientific signal and made it a headline in the title of each chapter of his tafsitr. Before further 
discussing the tafsîr, Zaghlûl described the verse's contents by briefly describing scientific facts and theories.

Zaghlûl's tafsîrs consists of four volumes. The first volume, starting from al-Baqarah to al-Isrâ', consists of 56 discussions of verses. The second volume, starting from al-Kahf to Luqmân, consists of 42 discussions. The third volume, starting from al-Sajadah to al-Qamar, consists of 38 discussions. Lastly, the fourth volume, starting from al-Raḥmân to alQâri'ah, consists of 40 discussions.

Zaghlûl's interpretation of the Quran includes three scientific fields, namely physics, biology, and health. Physics includes verses that discuss geology, astronomy, meteorology, and cosmology (Besancon 1990). Biology theme encompasses verses, which examine subjects such as embryology, physiology, zoology, botany, cytology, and genetics. Lastly, the health theme discusses Quranic verses discussing pathology and pharmacology (Ritner and McCabe 2004).

Among the aforementioned themes, geology may be considered most popular as it shares 47 interpreted verses. Following geology, astronomy comes second in terms of its popularity in Zaghlûl's work with 30 verses. Furthermore, embryology comes in the third place since it includes 23 verses. It is followed by zoology with 15 verses, meteorology with 13 verses, botany with 10 verses, and cosmology with 8 verses, while physiology, cytology, and genetics include seven verses. Lastly, pharmacology, and pathology can be classified as the least favorite theme as they with six verses for the former and three verses for the latter. The number of verses and their themes discussed in Zaghlul's interpretation is illustrated by figure 1 . 
Figure 1

Themes of scientific verses

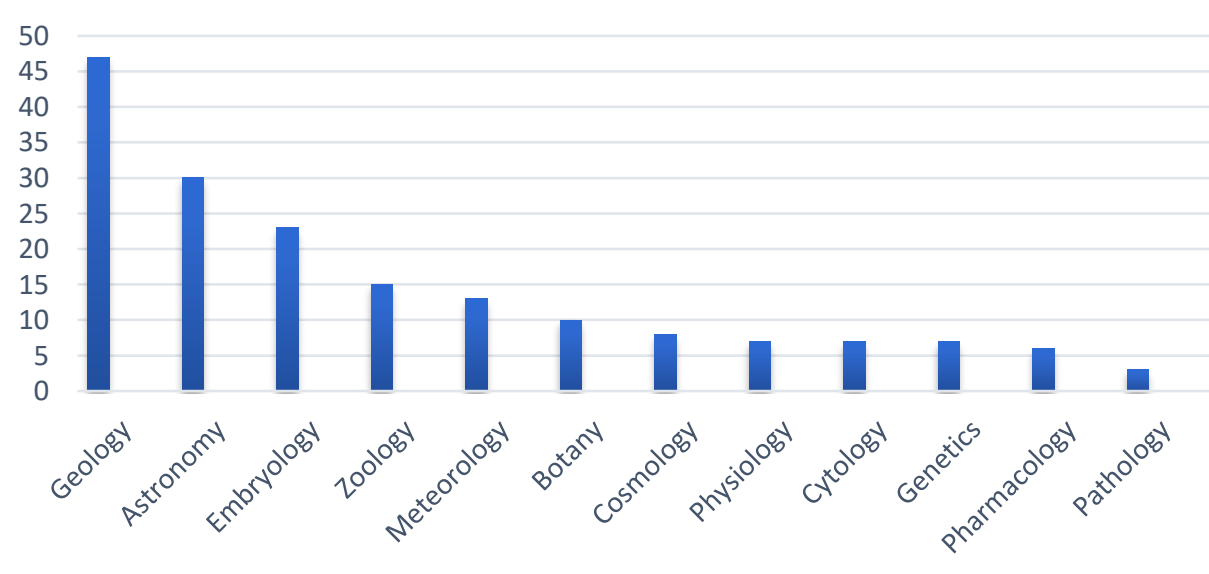

As seen in the graph, it is clear that Zaghlûl's background and his sensitivity as a geologist greatly influence the number of themes he raised, where he mostly raised themes about geology and the universe under his field of interest.

His experience and knowledge about the discipline of geology and his insight into the Quran's science has been an important asset for Zaghlûl in interpreting the Quran using scientific approach. He believes that it is an appropriate means of preaching, which is by showing the miracles of the Quran from the scientific side in the era where science and technology thrive. The progress achieved by science and technology makes humans even further away from their Creator.

The background of tafsîr creat ion is inseparable from Zaghlûl's view about the Quran itself. According to him, the number of scientific verses reaches a thousand verses, both explicitly and implicitly. The Quran is a divine revelation, apart from being a book of guidance, ișlâh, and tashrî̀ as well as a book of miracles with scientific facts that deserve to be revealed (alNajjâr 2005, 71; 2006, 25). In this position, the Quran may help Muslim scientists to explore and raise one of the theories and assumptions of science to the level of scientific nature. In other words, the Quran and hadith should become the rationale for finding scientific theories, not the other way around. In addition, the large number of kafir (infidels) and mushrik who deny the Quran as the words of Allah is a threat to Muslims. 
Therefore, discussing the miracles of the Quran from a scientific perspective through interpretation is a necessity.

Zaghlûl's critical for science and scientific method, which is considered to have limitations, and his view of revelation, which has unlimited truth, led him to the idea that between scientific and religious studies, there should be an intelligent, honest and not imposed interaction. If this is not done, then human knowledge will be partial and subjective, in addition to the secularization of knowledge and the separation between gnosis and wisdom (al-Najjâr 1986). Therefore, it should be clear that Zaghlûl's background in writing tafsîr is influenced by two factors. The first is to refute kafir, who denies the Quran, by proving the miracles of the Quran from a scientific perspective. The second is emphasizing that the Quran and scientific theory are not contradictory; they can be discussed and even integrated.

\section{Methods and Principles of Interpretation}

The dilemma of scientific exegesis of the Quran among Muslims, especially among expert interpreter, seems to stay. Furthermore, the pros and contra about the existence of the scientific exegesis of the Quran is difficult to avoid because of the doubts surrounding its validity. The source of the interpretation of scientific exegesis of the Quran, which is only temporary and relative, will be difficult when juxtaposed with the Quran, which is absolute. In addition, the view about whether there will be a correlation among modern scientific theories with the interpretation of the Quran verses might be a crucial issue. Even so, the scientific interpretation, especially among its supporters, is valid when carried out as long as the interpreter follows the procedure of interpretation, which are the rules and principles of scientific exegesis (Ali et al. 2017; Amir and Yusoff 2017; Bigliardi 2014; Çoruh 2020; Mutalib et al. 2019; Rahayu 2016; Sayska and Arni 2016; Supriadi 2017; Suskha, AM, and Wusqa 2020; Syamimi Mohd, Hussin, and Nasyrudin Wan Abdullah 2014; Syarifuddin and Azizy 2018).

The guidelines and the principle of interpretation serve as a tool that helps interpreters understand Quran to avoid interpretation errors, and distinguishes between the acceptable interpretations from the rejected interpretation (Ichwan 2004, 162). The scientific interpretation rules should be applied strictly, because the device used as the source material in forming the meaning of the text in Quran should be different with other types. However, it should also be recognized that any form of interpretation, with 
its own style or approach, should never be considered as is absolute or final. Therefore, it is not recommended for an interpreter to arrogantly claim that his interpretation is the truest explanation.

Some Islamic scholars such as Yûsuf al-Qaraḍ̂âî, Aḥmad Fâdil, Jamâl Mustafâ al-Najjâr, and Quraish Shihab provide rules in the form of guidelines in the scientific exegesis of the Quran that can be used as a foothold in interpreting the scientific verses. They aim to minimize the concern of the Islamic scholars over the subjectivity of the interpreter in understanding the scientific verses. Zaghlûl also applies the same approach in interpreting the context of the verse. He includes several disciplines that are embodied in some of the guidelines and principles of interpretation of the scientific verses.

The following are the guidelines and principles of interpretation suggested by Zaghlûl: First are the language aspects. Zaghlûl believes that the correct understanding of the Quranic text by the semantics, rules, and uslub of the Arabic language is the first step in the scientific exegesis of the Quran (al-Najjâr 2006, 70). Scholars agree that language aspects are an absolute requirement for interpreters who use the scientific approach (Hamîd 1984, 151). Islamic scientific exegete also needs to pay attention and considers the development of the word meaning. The understanding of a word can be seen in its material forms. However, in other aspects, they are subject to change following the development of society and science. Sometimes understanding a particular word in the Quran in the current era has a different meaning from the meaning used by the Arabs in the past (Shihab 2013, 81).

Second is the contextual aspects and asbâb al-nuzĥul as well as asbâb alwurûd if found (al-Najjâr 2006). Asbâb al-nuzûl refers to something that accompanies the revealing of the verses or as an explanation for an event in the Quran (al-Zarqânî 1988, vol. 1). Asbâb al-nuzûl serves to help comprehend the period and conditions the verse was revealed (Essack 2000). First are the verses related to one of the events or questions that arose at the time of the Prophet, both by companions and by the Quraysh. Second are the verses revealed without any events or questions that arose (al-Qațtân 2000). Zaghlûl, however, does not consider the aspects of the asbâb al-nuzûl as something urgent in the scientific exegesis of the Quran. In addition, an exegete of the Quran is demanded for understanding nâsikh-mansûkh, 'âm and khâs, mutlaq-muqayyad, mujmal-mufașsal if found (al-Najjâr 2006). 
Third is the interconnectedness of nass with a verse or other hadiths (munâsabah). According to Zaghlûl, in interpreting the scientific verses of the Quran, an exegete of the Quran should pay attention to the context of the paragraph without ignoring the relatedness of a verse with the verses before and after (al-Najjâr 2006).

Fourth is the theme. The thematic method, which is more popularly called as mawdûu $i$ method (al-Najjâr 2006), is a method of interpretation that incorporates or compares all the Quran verses and the relating hadith that has the same topic of discussion. The scientific exegesis paradigm is required to use thematic interpretation method to provide a thorough understanding. This method tries to find the answers in the Quran by collecting the verses, which have one goal. It aims to simplify and clarifies issues so that the discussion can be more complete and perfect (Suryadilaga et al. 2010, 57).

Fifth is how the exegete of the Quran should use already established scientific theory and should not impose any verse to becompatible with scientific truth (al-Najjâr 2006). Quran is seen as the book of revelation and the truth in it is absolute. Its authenticity and validity can be tested from various angles, both from history, language, the world of the unseen, even the scientific aspects. Thus, the Quran cannot be equated with the scientific theory, which is considered relative. An exegete of the Quran should not give meaning to the text of the Quran without an established scientific nature and should not stop until it reaches the standard of no rejection or change on the scientific statements (Ichwan 2004; Shihab 2013). Furthermore, an exegete of the Quran should hold on to the scientific fact, not a hypothesis or conjecture, and avoid imposition of the nass interpretation verses with scientific discovery.

Sixth, interpreters should avoid interpretation concerning the unseen or metaphysical such as the existence of a God, angels, jinn, yawm al-hisâb (day of reckoning), and others. They also need to avoid making an analogy of the afterlife using the provisions of the world, because the afterlife has its own laws and rules that are different from those of the world (al-Najjâr 2006). Zaghlûl seems to be very careful about his interpretation related to the unseen. In fact, he even tends to avoid discussing them. It is seen from the interpretation of lafaz (words) nûr (light) in Q.S. Yûnus [10]: 5 where he interprets it as the light of the moon that the light comes from other 
objects. However, he does not write any review of the word in Q.S. al-Nûr [24]: 35 that specifically describes God.

Seventh, an exegete of the Quran should be fahm al-ma'thûr to the interpretation of the Prophet Muhammad, his companions, the tâbi'în, and the scholars thereafter (al-Najjâr 2006). In this stage, the interpreter should know the interpretation of the Prophet in a text Quran and should be able to position the Prophet in a variety of his roles. The interpreter should be able to discuss the correct position between the text and the context. This also applies to the history of the Prophet's companions and the tâbi'în. They should be considered important in the interpretation because they had the honor and closeness to the Prophet peace be upon Him (Luthfi 2013, 77).

Eight, an exegete of the Quran should also collect a variety of correct and proper qirâ'ah and that are related to Quranic verses (al-Najjâr 2006). Nine, an exegete of the Quran should pay attention to the rules of al-ibrah bi 'umûm allafaz lâ bi khușụ al-sabab, and should be able to sum up the issue separately so that the scientific uniqueness in every verse can be seen. Ten, an exegete of the Quran should avoid discussing detailed information that does not correlate with the causes of scientific miracle of one or many verses in Quran. Eleven, an exegete of the Quran should understand the importance of distinguishing between being the researchers of texts of the Quran and people who quote the Quran by carefully considering establishing the specialty of the Quran. In this case, the scientific interpreter should not be encouraged to discuss every aspect of the scientific miracles with one science specialization that he or she has.

Twelve, an exegete of the Quran should emphasize that what is achieved by scientific researchers in understanding the verse should not the end of the understanding of the Quran. Thirteen, the interpreter should quote the literal phrases of the Quran verses to achieve the essence of nature, which may not be achievable kasab science. In his view, this is considered absolute and based on the belief that the Quran as is the word of God which has always been maintained throughout the fourteen centuries. Fourteen, the interpreter should not rule out ijtihâd of the previous scholars to understand the scientific verses with all their limitations and his day.

Fifteen, an exegete of the Quran should distinguish between the scientific miracles from the scientific interpretation related to the Quran. Sixteen, the interpreter should stress that the mistakes in interpretation that 
applies only to the interpreter and does not reduce the perfection of the Quran. Seventeen, an exegete of the Quran should have a strong belief in the truth of all that is there in the Quran, accompanied with a sincere intention (al-Najjâr 2006, 74; 2017a, 5; 2017b, 6).

This research finds twenty-one rules and the principles of interpretation suggested by Zaghlûl in some of his work. However, in this research, they are summarized into seventeen. This is because some rules are interconnected with the others that it should be sufficient to explain them in one single rule. Compared to the guidelines and principles of interpretation suggested by other scholars, this research sees that guidelines of interpretation suggested by Zaghlûl to be more specific and detail in which he represents two sciences at once i.e., theologian and scientist. In fact, it is believed that Zaghlûl develops the guideline and principles of exegesis that have previously existed.

Based on the finding of this research, if the aforementioned guidelines and principles of exegesis are applied in the scientific exegesis of the Quran, it would minimize errors and can be used to counter the criticism that has been appearing. However, the question is whether Zaghlûl himself uses the guidelines and principles that he suggests in interpreting the scientific verses or whether he merely suggests the theory of interpretation.

\section{Interpretation Analysis}

To see Zaghlûl's consistency interpreting scientific verses based on rules and principles that he suggested, this research here took one of his interpretations of the concept of light mentioned in Q.S. Yûnus [10]: 5.

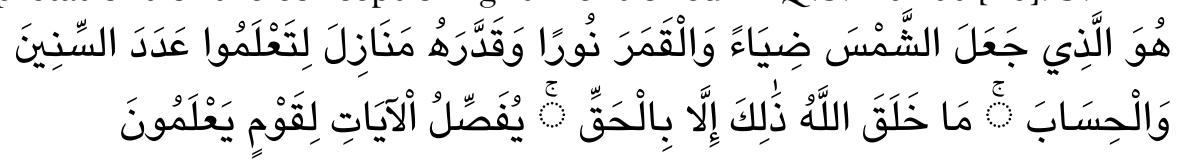

"It is He who made the sun a shining light and the moon a derived light and determined for it phases - that you may know the number of years and account [of time]. Allah has not created this except in truth. He details the signs for a people who know."

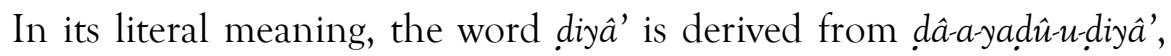
and this word is mentioned six times in the Quran, either in the form of a mastar or the verb. The word daw' means something that is spread from 
objects that glow. In al-Baqarah [2]: 17 and 20; and Yûnus [10]: 5, the word daw' is used for the word nâr (fire), al-barq (lightning), and al-shams (the sun). All three are luminous objects because of their own material (al-Aṣfahânî 2009, 513).

Zaghlûl started the interpretation of the verse by explaining the correlation between the diy $\hat{a}$ ' and the sun energy with a scientific approach with empirical data. Zaghlûl argued that diyấ (light) is the visible part of the electromagnetic power formed of a series of concatenated waves of photons that are not different from each other. Visible light, he added, is a collection of light electromagnetic energy that departs from the objects known by the rays of the sun. On the other hand, ray (daw') is the flow of photons which departs from the objects that light up, churned, and burned by itself. This can happen either because of the nuclear unification process, as it happened in the core the sun and in the body of the stars in the sky, or from the body of material spread in the electrons resulting from the work of electric heating or heat.

Furthermore, he explained that the electron from the highest level jumps towards the lowest level. The most important light source is the sun, whose core material is the process of unification of the nuclear (al-Najjâr 2008, vol. 1, 335-36; 2010, 20). Zaghlûl distinguished between the rays of the sun (diy $\left.\hat{a}^{\prime}\right)$ and the light of the moon (nûr) by explaining that the light of the sun undergoes a fission and reflection process when it falls to the surface of the moon. This surface is coated with various layers of thin glass due to the collision of a meteor into the surface, and the melting of the coral exists partially on the surface of the moon due to the collation. Therefore, it can be concluded that the moon is dark, cold, and not a radiant object. However, it has its potential to reflect the light of the sun to make it look radiant.

In addition, the following explains the difference between sunlight (daw') and the light of the moon (nûr). The moon's light is the result of the fission of the sun light on the surface of the moon through the electromagnetic force over the electric charge that contains all forms of matter. The frequency of the electromagnetic for the falling sunlight causes the occurrence of potential rotation pressure over all the charge of the electron that creates a motion that is in synergy with the frequency of the wave source of the white light (al-Najjâr 2008). 
Zaghlûl's interpretation is supported by the findings of a worldrenowned physicist, Isac Newton (d. 1643). He was the scientist who discovered the light known as the color of the rainbow by refracting white light particle into a prism. When the light particles from the sun cast on the surface of an object and they are reflected as right light, this means that the object, which reflects the light, is also red. It means that the object has absorbed all colors but the red one (M Yusuf, A., and Hatim 2007, vol. 4, 149).

On the other hand, Tantâwî Jawharî, as the pioneer of scientific exegesis in the modern era, focused the interpretation of Yûnus [10]: 5 on several aspects. One is the debate among scientist on the shape of the earth and the position of the earth and the moon when rotating and revolving around the sun. Two is the discussion about the benefits and hazards of the rays emitted by the sun to the people on earth. He argues that the sunray can be beneficial when used according to the body's ability to absorb it. By sunbathing in the warm sunlight, it is believed that humans can increase the immunity in their body, increase their appetite, regulate their blood circulation and the nervous system, and improve their liver function. However, the drawback may appear when human sunbath excessively, which may burn and peel off their skin (Jawharî 1922, vol. 5).

In addition to the Quran interpreters who focus on scientific exegesis, other interpreters interpret Q.S. Yûnus [10]: 5. Among them are Quraish Shihab and Ibn Kathîr. According to Shihab, Allah calls the sunlight as diyâa' as its light produces heat. Thus, it can be categorized as a celestial body that emits light from itself, which can be the source of power for the earth. Meanwhile, the term nûr emits weaker light and does not generate heat radiating from itself. Instead, it reflects the ray of the sun, which makes it seem luminous. Furthermore, the moon has a distinctive feature, as it can change its forms based on the location of the sun towards the earth, from which the months of qamariyah can be determined. Therefore, it may be concluded that the light of the sun comes the sun itself, while that of the moon comes from a reflection of the sunlight (Shihab 2009, vol. 5). In interpreting the kawniyyah verses, Shihab also utilized Zaghûl's interpretation as his references.

Meanwhile, Ibn Kathîr put more association between diyâ' and nûr as lights and the illuminator, in a sense that the light emitted by the sun and moon has its own functions. In addition, the orbit of the sun and the moon 
has different features. For instance, the sun is always in progress based on its particular period, while the moon always changes its position every night. These features have been used to determine the dates of Islamic events of worship such as Hajj and the fasting month of Ramadân among others (Indonesia Ministry of Religious Affairs 2012)

Based on the aforementioned interpretation, it can be concluded that both Ibn Kathîr and Quraish Shihab interpreted the word diyấ' and nûr based on their features, functions, and how beneficial the sun and the moon are in formulating qamariyah month and determining events of worship for Moslems. On the other hand, Jawharî focused on the debate on the shape of the earth, the earth and moon's rotation and its influence on astronomy, and the benefits and the dangers of sunray to the people on earth. Meanwhile, Zaghlûl interpreted diyâ' and nûr by explaining the process of how electromagnetic energy is created by the sun based on current modern scientific theory. Zaghlûl focused on describing the correlation between the verse and the theory of science related to the fundamental difference between the rays of the sun (divâa), with the light of the moon (n $\hat{u} r)$, and analogizes the sun as a lamp and the moon as a light (Q.S. Yûnus [10]: 5) coherently and in detail. The opposite of the word dark is light (nûr) and not ray (diyâa') (Q.S. al-An'âm [6]: 1). The characters of fire as light (diy $\hat{a}$ ) and the light that fell around it as the rays of nûr (Q.S. alBaqarah [2]: 17) Also, the description of the rays of lightning with light daw' in Q.S. al-Baqarah [2]: 20.

From the aforementioned interpretation, it can be concluded that Zaghlûl used rules of language in interpreting Q.S. Yûnus [10]: 5. This is supported by the fact Zaghlûl conducted a language analysis to distinguish the definition of the phrase "light of the sun" from "the light of the moon" to find that the result corresponds with the current theory of science. He also used an established theory to strengthen the interpretation. In his opinion, the theories he utilized are considered established modern science theories, which are highly unlikely to change. The aspects of munâsabah âyât (the correlation between paragraphs) are also present in his interpretation, and supported by the presence of quotations of related verses (which discuss similar themes) to strengthen his argument.

The utilization of the thematic method should be considered as the right step for Zaghlûl in interpreting kawniyyah verses to obtain a solid comprehension about diyâa' and nûr by quoting Q.S. al-An'âm [6]: 1, al- 
Ahzâb [33]: 45-46, and al-Nûr [24]: 35. He also avoids the metaphysical interpretation. For instance, he avoided Quranic word nûr contained in the al-Nûr [24]: 35 that is attached with the essence of God. However, it is worth noted that he never considered his interpretation as an absolute truth. He always believed that any errors in his interpretation are solely made by the exegete, and will never reduce the originality and the perfection of the Quran.

This means that Zaghlul applied the rules and principles of scientific exegesis he suggested, even though not the whole. From the beginning, Zaghlûl had emphasized the issue that all interpretation guidelines and principles can be simply applied immediately. This is because not all verses in the Quran possess asbâb al-nuzûl, munâsabah âyât, the occurrence of nâsikh-mansûkh, and the other aspects of 'ulum al-Qur'ân. To outline, it can be argued that Zaghlûl is somewhat consistent with the use of guidelines and principles he suggested in interpreting kawniyyah verses. His relevancy in his interpretation with the modern science theory, supported by the science authority both in Arabic language and in science, has become a benefit compared to his scientific exegete predecessors.

It is worth noted that, whether it is realized or not, the scientific interpreter sometimes is stuck on the apologetic attitude when confronted with the scientific verses. These verses are often interpreted as normative and approached by using the modern science theory of the West, which is considered only temporary to prove that Quran had discussed about it fourteen centuries ago, long before the theory was invented.

\section{Conclusion}

Zaghlûl Râghib Muhammad al-Najjar, a scientist and an exegete of the Quran suggests a set of ruleand principles in scientific interpretation of the Quran not only to understand but also to interpret Quran more objectively so that exegetes of the Quran can avoid making mistakes in making interpretation. Of the four traditions of interpretation that are agreed upon by the scholars of tafsîr, he added thirteen guidelines and principles that a scientific exegete must possess. Among others, the following are worth noted. First, an exegete of the Quran should avoid discussing detailed information, which does not correlate with the causes of scientific miracle. Second, the scientific exegete should not be encouraged to discuss every aspect of the scientific miracles with one science specialization that he or 
she has. Third, an exegete of the Quran should distinguish between the scientific miracles from the scientific interpretation related to the Quran. To add, Zaghlûl suggests a complete package of interpretation rules and principles, both in theory and in practice. In addition, he is adequately consistent in using them in interpreting scientific verses in his interpretation. Lastly, the relevance with the modern science in his interpretation of the Quran has been proven valid.

\section{References}

Abdullah, Amin. 2000. Kajian Ilmu Kalam di IAIN: Menyongsong Perguliran Pemikiran Paradigma Keilmuan Pada Era Milenium Ketiga. No. 65/VI. UIN Sunan Kalijaga Yogyakarta.

Abohashem, Ameen. 2012. "Al-Duktûr Zaghlûl al-Najjâr Yarwî Qișṣah Hayâtih.” Mp4. Tajrîbî. Mecca: https://www.youtube.com/watch?v=mDpt93xn7jE.

Ali, Amer Zulfiqar. 2018. "A Brief Review of Classical and Modern Tafsir Trends and the Role of Modern Tafasir in Contemporary Islamic Thought." Australian Journal of Islamic Studies 3(2): 39-52.

Ali, Mohammad, Rezai Esfahani, Mehi Bakouei, and Nematollah Jafari. 2017. "Scientific Approach in the Interpretation of the Koran Based on the Requirements of the Time, Relying on Mainstreaming." Journal of Novel Applied Sciences 6(4): 102-12.

Amir, Selamat, and Zulkifli Mohd Yusoff. 2017. "The Cintemporary Scientiific Interpretation of Al-Qur'an: A Review on Al-Sha'rawi's Method in Tafsir." Quranica: International Journal of Quranic Research 9(1): 156-57.

DOI: https://doi.org/10.22452/quranica.vol9no1.3

Amir, Selamat, Monika, Mohd Yakub, and Zulkifli Yusoff. 2016. "Epistemology of Scientific Interpretation of the Qur'an: A Study on Zaghlûl al-Najjar's Approach in Interpretation al-Kawniyyat Verses." Jurnal Perspektif 7(2): 59-60.

Amir, Selamat, Moh Murshidi Noor, and Ahmad Bazli Hilmi. 2012. "Scientific Assimilation in the Interpretation of the Qur'an: An 
Approach to Zaghlûl's Work Entitled "Tafsîr al-Âyah al-Kawniyyah fî al-Qur'ân al-Karîm." Al-Bayân Journal 10(2): 46-67.

DOI: https://doi.org/10.11136/jqh.1210.02.04

'Ammâr, Aḥmad Mukhtâr. 2008. Mu'jâm al-Lughah al'Arabiyyah alMu'âsarah. Cairo: 'Alam al-Kutub.

al-Asfahâni, al-Râghib. 2009. Mufradât Alfâz al-Qur'ân. Damascus: Dâr alQalam.

Awang, Ramli, Kamaruzzaman Yusoff, Badlihisham Mohd Nasir, and Mohd Nasir Ripin. 2014. "The Impact of Separation Between Science and Religion: An Observation." The Social Science 9(1): 37-41.

Besancon, Robert M. 1990. The Encyclopedia of Physics. New York: Springer Science and Business Media.

Bigliardi, Stefano. 2014. "The Contemporary Debate on the Harmony between Islam and Science: Emergence and Challenges of a New Generation." Social Epistemology 28(2): 167-86.

DOI: https://doi.org/10.1080/02691728.2013.782583

Companini, Massimo. 2005. "Quran and Science: A Hermeneutical Approach.” Jurnal of Quranic Studies 7(1): 48-63.

Çoruh, Hakan. 2020. "Relationship Between Religion and Science in the Muslim Modernism.” Theology and Science 18(1): 152-61.

DOI: https://doi.org/10.1080/14746700.2019.1710355

al-Dhahabî, Muhammad Husayn. 1959. al-Tafsîr wa al-Mufassirûn. Cairo: Maktabat Wahbah.

Essack, Farid. 2000. Membebaskan yang Tertindas: al-Qur'an Liberalisme, Pluralisme. Trans. Watung A. Budiman. Bandung: Mizan.

Hakim, Rahman. 2019. "Tafsir Salman dalam Perspektif Metodologi Tafsir Ilmi Ahmad al-Fadil.” Ph.D Theses. Universitas Islam Negeri Sunan Ampel Surabaya.

Hamîd, Muḥsin 'Abd. 1984. Dirâsât fî̀ Tafsîr al-Qur'ân. Egypt: Dâr alThaqâfah.

Ichwan, Muhammad Noer. 2004. Tafsir Ilmi: Memahami al-Quran Melalui Pendekatan Modern. Yogyakarta: Menara Kudus. 
Indonesia Ministry of Religious Affairs. 2012. Tafsir Ilmi: Manfaat BendaBenda Langit Dalam Perspektif al-Quran dan Sains. Jakarta: Lajnah Pentashih Mushaf al-Quran.

Iqbal, Muzaffar. 2018. Islam and Science. New York: Revivals Routledge.

Jansen, J.J.G. 1997. The Interpretation of the Koran in Modern Egypt (Diskursus Tafsir al-Quran Modern). Trans. Hairussalim and Syarif Hidayatullah. Yogyakarta: Tiara Wacana.

Jawharî, Ṭantâwî. 1922. Al-Jawâhir fî Tafsîr al-Qur'ân. Egypt: Mușțafâ al-Bâbî al-Halabî.

al-Khâlidî, Ṣalâh 'Abd Fattâh. 2008. Ta'rîf al-Dârisîn bi Manâhij al-Mufassirîn. Damascus: Dâr al-Qalam.

Khir, Bustami Muhammed. 2000. "The Qur'an and Science: The Debate on The Validity of Scientific Interpretation." Journal of Qur'anic Studies 2(2): $19-35$.

DOI: https://doi.org/10.3366/jqs.2000.2.2.19

Luthfi. 2013. Epistemologi Tafsir Sains Zaghlûl Al-Najjar. Magelang: PKBM Ngudi Ilmu.

M Yusuf, A., and M.A Hatim. 2007. Ensiklopedia Metodologi Al-Quran. Jakarta: PT Kalam Publika.

Mir, Mustansir. 2004. "Scientific Exegesis of The Qur'an-A Viable Project?" Journal Islam and Science 2(1): 33-42.

Mohd, Nor Syamimi, Haziyah Husin, and Wan Nashruddin Wan Abdulah. 2014. "Scientific Exegesis in Malay Quranic Commentary." Asian Social Science 10(10): 236-42.

DOI: https://doi.org/10.5539/ass.v10n10p236

Mohd, Nor Syamimi, Haziyah Husin, and Wan Nashruddin Wan Abdulah. 2016. "Re Definition of Term Al-Tafsîr al-ilmî: Scientific Exegesis of al-Quran." Jurnal Islamiyyat 38(2): 149-51.

DOI: https://doi.org/10.17576/islamiyyat-2016-3802-07

Muchlisin, Annas Rolli, and Khairun Nisa. 2017. "Geliat Tafsir Ilmi di Indonesia dari Tafsir Al-Nur hingga Tafsir Salman.” Millati: Journal of Islamic Studies and Humanities 2(2): 239-57.

DOI: https://doi.org/10.18326/mlt.v2i2.239-257

Ulul Albab Volume 21, No.2 Tahun 2020 
Mufid, Fathul. 2014. "Islamic Sciences Integration.” QIJIS 2(2): 145-60.

DOI: http://dx.doi.org/10.21043/qijis.v2i2.1565

Mustaqim, Abdul. 2010. Epistemologi Tafsir Kontemporer. Yogyakarta: LKiS.

Mutalib, Lukman Abdul et al. 2019. "Scientific Exegesis of Al-Quran and Its Relevance in Dealing with Contemporary Issues: An Appraisal on the Book of al-Jawahir fi Tafsir al-Quran al-Karim.” International Journal of Recent Technology and Engineering 8(2 Special Issue 11): 575-81.

al-Najjâr, Zaghlûl Râghib. 1986. "The Limitation of Science and The Teachings of Science from The Islamic Perspective." American Journal of Islamic Social Science 3(1): 59-73.

al-Najjâr, Zaghlûl Râghib. 2005. Min Âyât al-I'jâz al-'Ilmî: al-Arḍ fî al-Qur'ân alKarîm. Beirut: Dâr al-Ma'rifah.

al-Najjâr, Zaghlûl Râghib. 2006. Min Âyât al-I'jâzz al-'Ilmî: al-Hayawân fî alQur'ân al-Karîm. Beirut: Dâr al-Ma'rifah.

al-Najjâr, Zaghlûl Râghib. 2008. Tafsir al-Âyât al-Kawniyyah fí al-Qur'ân alKarîm. Cairo: Dâr al-Shurûq.

al-Najjâr, Zaghlûl Râghib. 2010. Mukhtârât min al-Tafsîr al-Âyât al-Kawniyyah fî al-Qur'ân al-Karîm. Egypt: Maktabat al-Shurûq al-Dawliyyah.

al-Najjâr, Zaghlûl Râghib. 2017a. Min Âyât al-I'jâz al-'Ilmî bi sûrat al-An'âm wa al-Hajj. Cairo: al-Bidâyah.

al-Najjâr, Zaghlûl Râghib. 2017b. Min Âyât al-Mâ' fî al-Qur'ân. Cairo: alBidâyah.

al-Qațân, Mannâ'Khalîl. 2000. Mabâhith fî 'Ulûm al-Qur'ân. Beirut: Dâr alFikr.

Rahayu, Muliza. 2016. "Integration Between Religion and Science in Early Childhood Education Learning." Ta'dib 20(2): 201-20.

DOI: https://doi.org/10.19109/tjie.v20i2.223

al-Raḥmân, Fath 'Abd. 1986. Ittijâh al-Tafsîr fî al-Qarn al-Râbi' 'Ashar. Saudi Arabia: Mamlakat al-'Arabiyyah al-Sa'ûdiyyah.

Ritner, Don, and Timothy McCabe. 2004. Encyclopedia of Biology. New York: Fact on File Published. 
Saleh, Sujiat Zubaidi. 2011. "Epistemologi Penafsiran Ilmiah Al-Quran." Tsaqafah: Jurnal Peradaban Islam 7(1): 109-31.

DOI: http://dx.doi.org/10.21111/tsaqafah.v7i1.112

Sayska, Dwi Sukmanila, and Jani Arni. 2016. "Evidences of Scientific Miracle of Al-Qur'an in the Modern Era." Jurnal Ushuluddin 24(1): 79-90.

DOI: http://dx.doi.org/10.24014/jush.v24i1.1481

Shahrûr, Muhammad. 1992. al-Kitâb wa al-Qur'ân: Qirâ'ah Mu'âṣirah. Damascus: Âhâlî al-Nașr wa al-Tawzî‘.

Shaleh, Sujiat Zubaidi, and Intan Pratiwi Mustikasari. 2018. "Al-Ishtifa'i bi al-'Asl fî al-Qur'ân “inda Zaghlûl Râghib al-Najjâr.” Studi Quranica 3(1): $1-15$.

DOI: https://doi.org/10.21111.

Shihab, M. Quraish. 2004. Mukjizat Al-Quran Ditinjau dari Aspek Kebahasaan, Isyarat Ilmiah, dan Pemberitaan Hal Ghaib. Bandung: Mizan.

Shihab, M. Quraish. 2009. Tafsir Al-Misbah: Pesan Kesan dan Keserasian AlQuran. Jakarta: Lentera hati.

Shihab, M. Quraish. 2013. Membumikan Al-Quran. Jakarta: Lentera Hati.

Supriadi, Akhmad. 2017. "Integrating Qur'an and Science: Epistemology of Tafsir Ilmi in Indonesia." Refleksi 16(2): 149-86.

DOI: https://doi.org/10.15408/ref.v16i2.10191

Suryadilaga, Al-Fatih, Abdul Lathif, Yudhi Munadi, and Firdaus. 2010. Metodologi Ilmu Tafsir. Yogyakarta: Teras.

Suskha, Ahlam, Rusydi AM, and Urwatul Wusqa. 2020. "The Benefits of Water for Plants: The Perspectives of Al-Qur'an and Science." AL QUDS: Jurnal Studi Alquran dan Hadis 4(2): 447-66.

DOI: http://dx.doi.org/10.29240/alquds.v4i2.1883

Syarifuddin, M. Anwar, and Jauhar Azizy. 2018. "Thematic Scientific Interpretation of the Qur'an in Indonesia." In Advances in Social Science, Education and Humanities Research (ASSEHR), 43-50.

DOI: https://doi.org/10.2991/icqhs-17.2018.7

al-Zarqânî, 'Abd 'Azîm. 1988. Manâhil al-'Irfân fî̀ 'Ulûm al-Qur'ân. Beirut: Dâr al-Fikr.

Ulul Albab Volume 21, No.2 Tahun 2020 